\title{
Volcano Project Design: Innovation In Geoscience Learning
}

\author{
Eko Hariyono, "Binar Kurnia Prahani, M. Mardiyanti \\ Postgraduate of Science Education, Universitas Negeri Surabaya, Jl. Ketintang Surabaya, \\ Indonesia \\ *Corresponding Author e-mail: binarprahani@unesa.ac.id \\ Received: November 2020; Revised: November 2020; Published: December 2020
}

\begin{abstract}
The research aim was to develop the Volcano Project Design (VPD) for improving the physics student research skills about volcano. The method used is a qualitative analysis The research sample involves 34 undergraduate of physics students. The instrument used in VPD was equipped with the assessment format and rubric that was developed by researchers. The instruments tools were validated by experts in the field of geoscience and volcanology. The VPD guide contains the theoretical basis of fieldwork, descriptions of activities, project themes and targets to be achieved, phases of activities, and assessment of activities in the field. In addition, in the guidelines is also equipped with a guide of proposal preparation, field report and research products. The important results showed that the physics students were succeeded in conducting volcano research using VPD. This result was supported by the capabilities to identifying some crucial problems about volcanoes, presenting some solution based on several issues that have been identified and providing an accurate explanation of volcanic phenomena. The interesting finding based on research is the students' research product as new information in geoscience. Even though needs intensive guidance, the product has an opportunity to be published broadly. Based on students' perception, the program succeeded to build students' scientific attitude, constructing a positive value to the environment around the volcano and perfectly prepare students to help the community in the face of volcanic disasters.
\end{abstract}

Keywords: Volcano project design; research skills; geoscience learning

How to Cite: Hariyono, E., Prahani, B., \& Mardiyanti, M. (2020). Volcano Project Design: Innovation In Geoscience Learning. Prisma Sains : Jurnal Pengkajian Ilmu dan Pembelajaran Matematika dan IPA IKIP Mataram, 8(2), 139-149. doi:https://doi.org/10.33394/j-ps.v8i2.3267

https://doi.org/10.33394/j-ps.v8i2.3267

Copyright $\odot$ 2020, Hariyono et al This is an open-access article under the CC-BY License.

\section{INTRODUCTION}

The volcano is one of the potential geoscience learning resources in Indonesia. Considering almost all the Indonesian islands have volcanoes surrounding, the environmental impacts of volcanic eruption and the low level of community knowledge and skills are interesting issues in geoscience learning. Unfortunately, this information not yet widely accommodated in learning, especially to develop volcanoes research skills of physics students. Limitation of learning resource and lack of interaction in learning process with the environment led to the students' geoscience misconception. Several studies show that the misconception is strongly influenced by the concepts taught (Tongsakul \& Jitgarun, 2006). Students only have a few opportunities to conduct authentic research on the environment and communicate the findings of scientific investigations (Koretsky et al., 2012). Understanding of the environmental problems is very important in life. The lack understanding of the environment, make it difficult for us to assess the situation and behave optimally (Zoldosova \& Prokop, 2006) in solving environmental problems.

The research skills excavated in learning activities will provide many academic advantages in mastering the concept and development of the field of professional work (Reisberg, 1998; Dominick et al., 2000; Ishiyama, 2002; Seymour et al., 2004; Willison, 
2012). It is necessarily an authentic Geoscience learning strategy in building and developing knowledge, skills, and attitudes (Nelson et al., 2010; Baber et al., 2010; Filipe de Baros et al., 2012; Adetunji et al., 2012; Goldsmith et al., 2013), problem-solving skills (Lee et al., 2014) as well as integrated with the environmental problems (Roberts et al., 2010; Scott, 2014).

A fundamental objective of the geoscience education is to ensure that all people have an understanding of the natural processes of the environment and human activities impact on the earth (Locke et al., 2012). This is consistent with the concept of NGSS (Next Generation Science Standards) specifically to improve understanding of the community challenges and facing the associated with the complex environmental problems (Ladue \& Manning, 2015).

Volcano Project Design (VPD) is a part of project-based learning activities that conducted outside the classroom. It is an important part in the field of geoscience curriculum (Piburn et al., 2011). This activity focused on the investigation of geological phenomena around volcanoes. The students will be trained in all aspects (Wulf, 2013) and performed in a wide variety of methods (Mccafrrey et al., 2005) in the activity. The VPD consists of field data collection, geographic information system, modeling, and experimentation (Young et al., 2016). It was provided with many benefits for students, in developing students' conception (Stokes et al., 2011), personal competency (Esteves et al., 2013), academic professional (Petcovic \& Stokes, 2014) and also provides several pedagogical advantages (Hope, 2009).

The important parts in VPD are recording, analyzing and publishing the results of field observations, measuring and interpreting (Stumpf, 2012). It is expected to develop some capability in geoscience (Fermeli et al., 2014).Through this program, students are not only given knowledge, but they were trained to apply the basic principles of geoscience in solving problems through fieldwork (Wysession, 2013). Great planning was implemented through VPD is designing of volcano projects to transform and analyze the potential for natural disasters around volcano based on direct observation. Other plans are explaining the impact of the eruption on the changes in the landscape and vegetation by comparing conditions before and after the eruption. An interesting experience in the activities of volcano project was investigating the characteristics of volcanoes based on the rock-forming, predicting characteristics of eruptions that have occurred, investigating the social conditions of the people and environment around volcanoes that was associated with adaptability as a form of mitigation of volcanic disasters and exploration to identify the potential of natural resources that can be utilized for the community around the volcanoes area.

Problem Solving Fieldwork attempts to overcome some of the difficulties and limitations of the previous models. It encompasses three moments: before the trip (formulation of a problem, which students answer through conceptual or empirical research); the trip (This activity stimulates reflection and improves reasoning through the justification of statements leading to new questions) and after the trip (students and teachers reflect on the different stages of the process (Filipe de Baros, Almeida \& Cruz, 2012). The VPD was modified from the problem-solving fieldwork that was developed by Filipe de Baros, Almeida \& Cruz (2012). The VPD emphasized to physics students' research skills about volcanic phenomena, which this does not yet exist in the model developed by Filipe de Baros, Almeida \& Cruz (2012). The VPD is supported by the theory of meaningful learning by David Ausbel in which students will find it easier to gain long-lasting knowledge and skills. Therefore, the research aim was to develop the Volcano Project Design (VPD) for improving the physics student research skills about volcano. The field activity was held in Tangkuban Parahu Natural Park, one of the volcano tourist' destination in West Java-Indonesia.

\section{METHOD}

\section{Participant}

The research participant is 34 undergraduate of physics students at Physics Department of Science and Mathematics Education Faculty, in one of the state university in West JavaIndonesia. They are taking Earth and Space Sciences courses during the odd semester. The 
subject was divided into 6 groups consisting of 5-6 students to conduct field research in accordance with the theme chosen randomly. All groups received the same briefing in preparation for the practice of field activities.

\section{Research design}

The field activity was held in Tangkuban Parahu Natural Park, one of the volcano tourist' destination in West Java-Indonesia. The uniqueness of Tangkuban Parahu is the result of Sunda Mountain eruption that produced a very beautiful topographic pattern. They have a variety of information sources that can be utilized as a learning resource in volcano project. The characteristics of endemic animal and vegetation due to the influence of volcanic environment become a surprising object in the field research. Various rock types and social behavior at Tangkuban Parahu around is very interesting to study through volcano project.

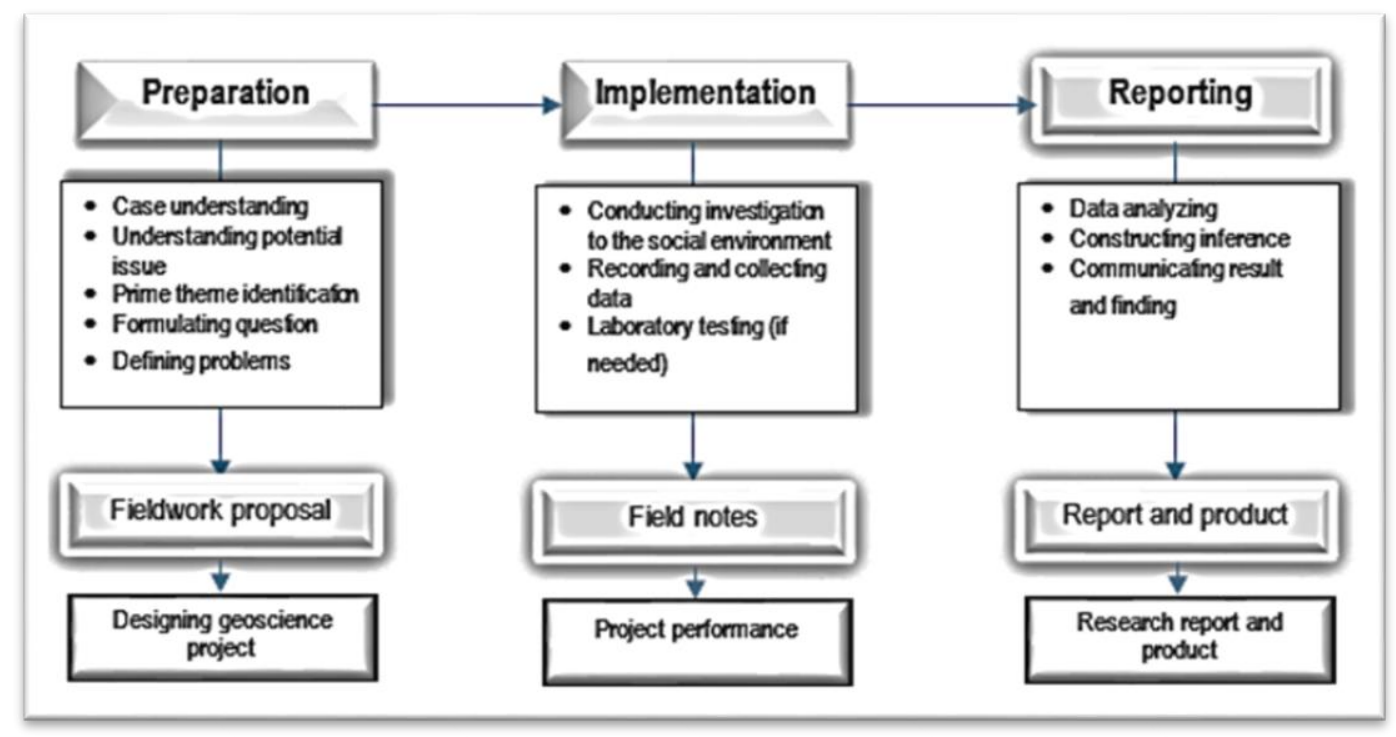

Figure 1. Theoretical Framework of Volcano Project Design (VPD)

The VPD has three stages, consist of preparation stages, implementation, and reporting (Fig. 1). The VPD has been declared valid by the experts. The data collected from the ability to design a project according to all issues that have been identified, conducting volcano fieldwork, create reports according to field observation results and constructing research product in the form of papers or posters. The volcano project activity was oriented to the project themes and targets that arrange based on the identification result of the flourish issues in volcano. Project themes and targets contribute students to control field activity, so it's more focused and in accordance with the expected. All the project themes and targets can be seen in Table I.

Table 1. Volcano Project Themes

\begin{tabular}{cll}
\hline No & \multicolumn{1}{c}{ Project themes } & \multicolumn{1}{c}{ Targets } \\
\hline 1 & $\begin{array}{l}\text { Hazard map and potential } \\
\text { volcanic disasters }\end{array}$ & $\begin{array}{l}\text { Making a hazard map based on the potential } \\
\text { disaster in the vicinity of the volcano. }\end{array}$ \\
$\begin{array}{l}\text { People's behavior around } \\
\text { volcanic in the face of eruption } \\
\text { disaster }\end{array}$ & $\begin{array}{l}\text { Investigating the human adaptation in the } \\
\text { volcanic' area. }\end{array}$ \\
$\begin{array}{l}\text { Changes in vegetation around } \\
\text { volcano }\end{array}$ & $\begin{array}{l}\text { Identify the plants of physiological changes due } \\
\text { to the eruption. } \\
\text { The physical properties of } \\
\text { volcanic rock }\end{array}$ & $\begin{array}{l}\text { Making a prediction model based on the } \\
\text { characteristics of the volcanoes rock's chemical } \\
\text { composition. } \\
\text { Exploring the geological phenomenon in the } \\
\text { vicinity of the volcano. }\end{array}$ \\
\hline
\end{tabular}




\begin{tabular}{cll}
\hline No & \multicolumn{1}{c}{ Project themes } & \multicolumn{1}{c}{ Targets } \\
\hline 6 & $\begin{array}{l}\text { Potential natural resource of } \\
\text { volcanoes that has an opportunity } \\
\text { to be developed }\end{array}$ & $\begin{array}{l}\text { Designing a mini project to develop volcanic } \\
\text { potential. }\end{array}$ \\
\hline
\end{tabular}

In addition, assessing the physics students' research skills about volcano, made measurements on student perceptions of VPD that are implemented in geoscience learning. This is done as a form of data triangulation to ensure conformity of research results.

\section{Research Instrument}

The instrument used in VPD was equipped with the assessment format and rubric that was developed by researchers. The instruments tools were validated by experts in the field of geoscience and volcanology. The VPD guide contains the theoretical basis of fieldwork, descriptions of activities, project themes and targets to be achieved, phases of activities, and assessment of activities in the field. In addition, in the guidelines is also equipped with a guide of proposal preparation, field report and research products.

\section{Data collection and analysis}

Obtained data were displayed in tables and graphs. All data were assessed based on the rubrics that have been developed by researchers and analyzed quantitatively. Score assessment based on criteria, 0.0-1.0 (bad); 1.1-2.0 (enough); 2.1-3.0 (good); 3.1-4.0 (very good).

\section{RESULTS AND DISCUSSION}

\section{Preparation stage}

At the stage of preparation for carrying out the VPD, the students involved in the case and understanding the potential issues associated with the volcano. Based on these activities, students were able to formulate questions and defining problems or project design. Results that obtained from the preparation stage were proposals of field activities based on the project's theme selected. The proposals have been submitted by groups with the number of 56 students. The fieldwork proposal judged on five criteria, i.e. the ability to identifying problems, complexity design, research relevance, the methods used and research instruments.

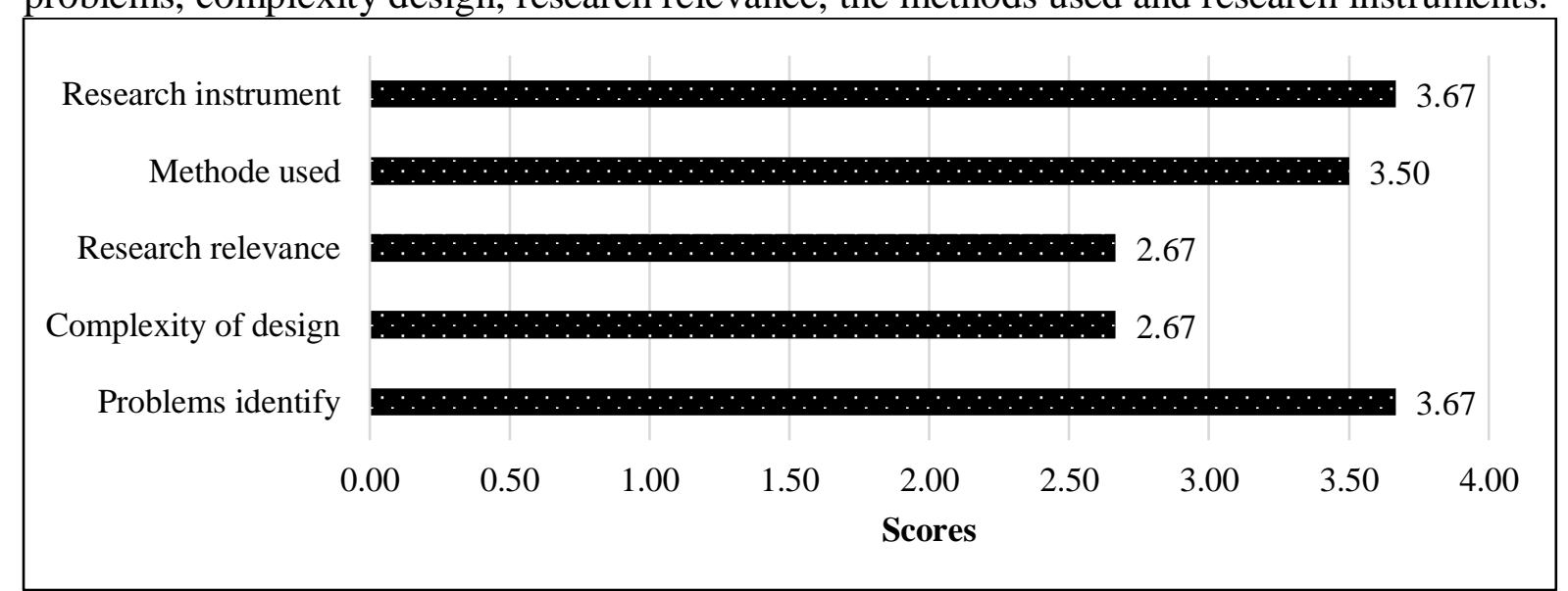

Figure 2. Results of the assessment of volcano project proposal

The assessment results of student's preparing volcano research proposal can be seen in Figure 2. Based on the figure, all aspects of the proposal are good and very good levels. The lowest score in preparing stage is the ability to access the relevant research used and the complexity of research design (2.67). The highest score was to identify problems and make research instruments (3.67). Based on the research proposals, the average of physics students has difficulties in accessing relevant literature underlying the research activities, because each proposal only supported of not more than two reliable literature as the basis of theoretical 
studies. While related to the complexity of research design, they were not able to present systematically associated with the stages of problem-solving that have been identified.

\section{Implementation stage}

In the implementation stage, students carried out the volcano project, according to proposal design. Students conducted an investigation about the environment and society around the volcano and recording and collecting data based on the observation. At this stage, the students make field notes as the basic of preparing the report of field activities and research products. In carrying out the volcano project, the assessment was based on four criteria. There are the group dynamics, collaboration within the group, the ability to access and organizing data, and the suitability of activities planned. The conformity of plans with activities in the field is strongly influenced by the completeness of information about the research object. The lack of curiosity and the low of effort to find information related to the characteristics of the object under the study became the main reason for the incompatibility between field activities and what was planned. However, these activities make students have new challenges that motivates them to work together in carrying out the volcano project.

\section{Reporting stage and research product}

The research report is a summary of field activities. There are four assessment criteria, consist of the documentation report, offered solution, interpretation result, and time management. Based on the Fig. 3a, we can see that the average score of report documentation is very good (3.83). The student has the weakness in the time management to get finished of field report. Time management is still a major obstacle in completing the task perfectly. That was influenced by the condition of students who have to deal with multiple tasks and they have not been trained in making priority scale.

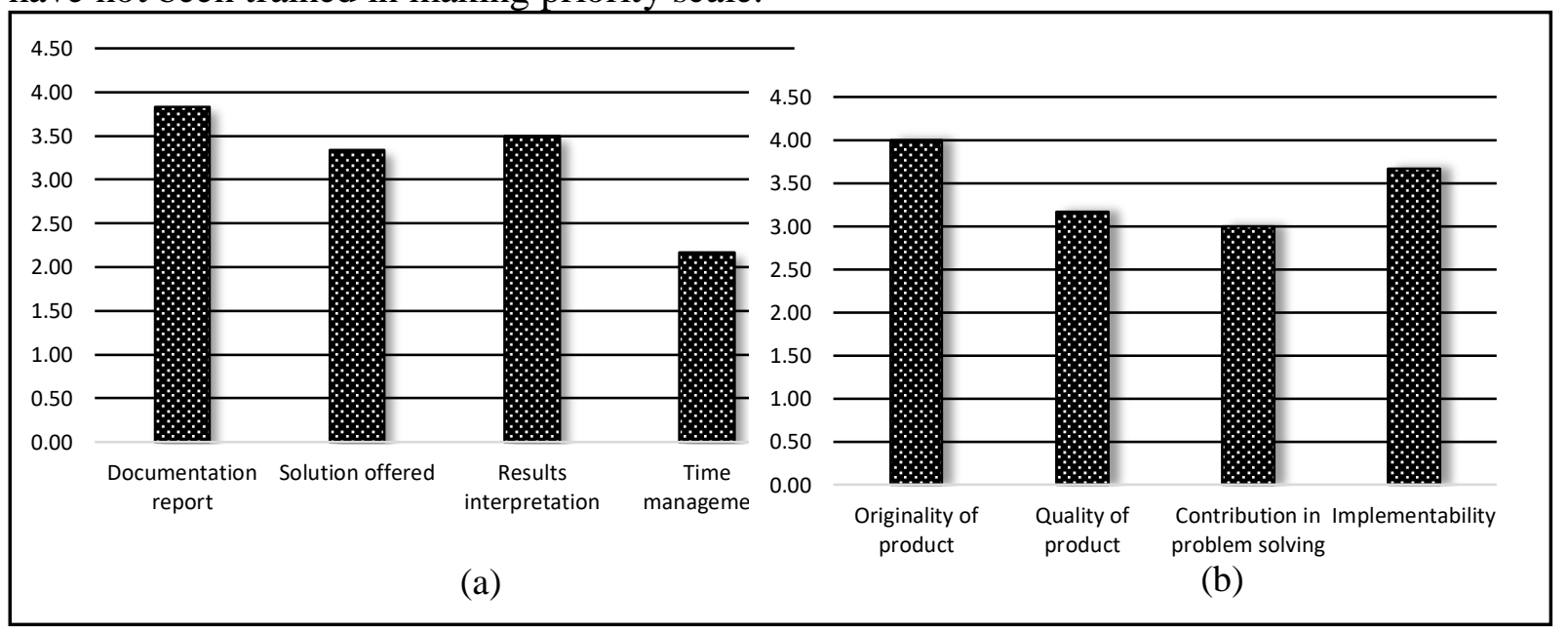

Figure 3. Results of the assessment of (a) field report, (b) research product

Papers or posters (Figure 4) as research product were created by the students as research results communication in writing. Based on the Figure $4 \mathrm{~b}$, it appears that the products of all of the groups have a high score of originality. This means a new invention that deserves could be published. In the constructing of papers or posters, all aspect have good and very good level, especially originality product that has a high score (4.00). Even though all aspects are good, the lowest scores are product contribution of problem-solving (3.00) and quality (3.17). Based on these results, the students have a good chance to be implemented the results in the volcanoes' communities around. 


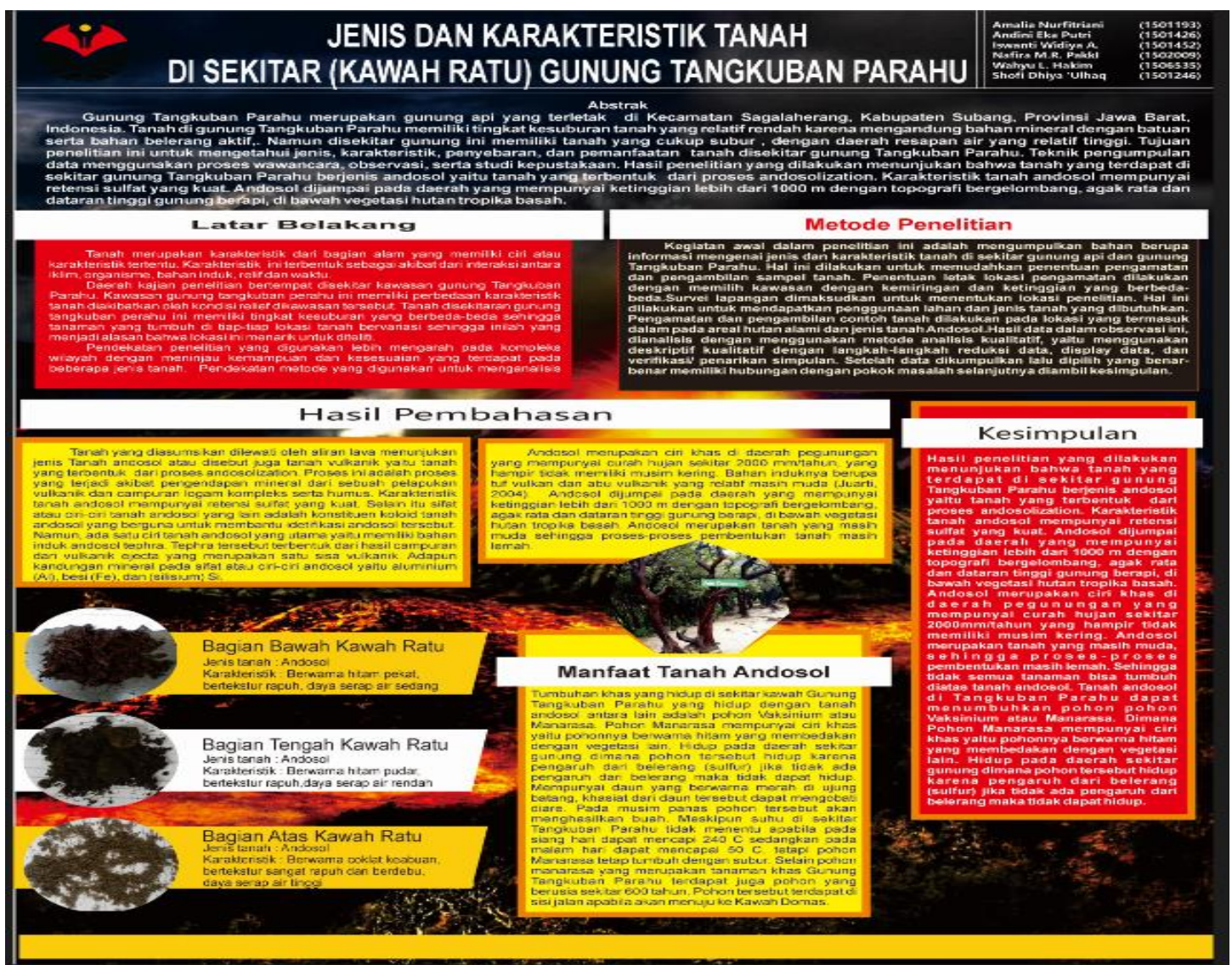

Figure 4. The students' poster about soil characteristics of Tangkuban Parahu

Based on the six themes according to all issues was identified, we should notice volcano project finding in Table 2. Sometimes between planning and initial targets are inconsistent with the field results. This is important findings in research of volcanic phenomena. The results of volcano project were useful for the community in developing adaptation capabilities around the volcano. Moreover, these results provide opportunities for students to conducting research more intensively and effectively.

Table 2. The six summary findings of volcano projects

\section{The titles}

Disaster areas and potential catastrophic on Tangkuban Parahu mountain

The behavior of community in the area with a radius of $1.5 \mathrm{~km}$ from the slopes of Tangkuban Parahu The Influence of Tangkuban Parahu environmental factors to the endemic vegetation

Getting to know the characteristics of the rock and Tangkuban Parahu eruption

The type and characteristics of soil in TangkubanParahu

\section{Volcano project findings}

Disaster area in the region of Tangkuban Parahu is the north and south areas. The south side has the potential for an earthquake with a higher frequency. The northern area has low-frequency earthquakes, but are vulnerable to the danger of ash and gases released by volcanoes during the eruption.

The community is less understood to the magnitude of hazard due to the eruption of Tangkuban Parahu. However, the public due attention to the signs of the eruption by previous eruptions experience.

Manarasa is an endemic vegetation. They have long creeping roots, big, and strong. Roots hefty lead it became adaptation evidence as one of the trees that can survive in extreme environmental conditions.

The type's rock dominantly in Tangkuban Parahu is basaltic and andesitic rocks. The $\mathrm{SiO}_{2}$ content is around $45 \%-56 \%$ and includes ultramafic igneous rocks.

The soil types in the surrounding area of Tangkuban Parahu are andosol types also called volcanic soils that formed from 


\section{The titles}

\section{Volcano project findings}

the andosoliation process.

Utilization of sulfur in the mountain region of

Tangkuban Parahu as a water purifier.

purification materials

In general, the volcano project design was considered successful in supporting geoscience learning, especially in developing volcano research skills. Some interesting were presented by students in VPD, they were considered very important in understanding of the circumstances, making the right decisions and preparation of things beyond the allegations associated with the volcano phenomenon. In addition, students were able to undertake the real about the volcano and it was expected that the scientific potential in students emerges through the interesting method. Using hands-on experience through VPD, students gained much knowledge about volcano and capable to improve volcanic research skills.

Learning through the volcano project design was able to improve the understanding of the geoscience concept, constructing research skills and help transform the abstract concept into tangible. The integration of volcano project in learning activities makes a significant contribution to the physics students' research skills in geoscience. This skill was needed both now and in the future. Through VPD, it can be obtained information more clearly about volcano as it has been defined through a model or theoretical criteria (Church, 2013).

Based on the research results can be seen that the physics students' research skill of volcanic phenomenon is good. This statement has been supported by students' ability in preparing volcano project proposals, conducting the project, reporting and constructing a research product. Through the volcano project, students could learn how to work in groups, learning about the importance of observation, documentation, and recording as part of the scientific method (Buddington, 2006), and enhancement of the content knowledge through research projects (Kortz \& Kraft, 2016). Many experts agree that the fieldwork is fun and highly effective learning strategy to provide learning experiences (Çalişkan, 2011; Efstratia, 2014).

Despite many limitations to transfer the classroom knowledge to the environment (Waldron et al., 2016), the average student has been able to identify the problem properly and pour it in the form of proposals. These aspects considered less are the complexity of the research design and the use of research relevant. These were utilized as a scientific foundation to plan of volcano projects. The research design does not merely cover of the research limitation, but also how the research was carried out and describes what is required (Verschuren \& Doorewaard, 2010).

The discrepancy between the plan and the conditions in the field are often the main factor cause difficulties in carrying out the volcano field work. The research design based on the field problems is more likely to be implemented because it is able to be conducted effectively (Naikar, 2017). The designing research skill depends on field knowledge and use of relevant information related to the research and the object being studied. Lack of support and access to relevant information is the prime reason the difficulties in developing a research design well.

Some of the problems that arise when students carry out the volcano field work, among others, students less skilled in accessing information about the rocks. They have not a technique in exploring the geological information. Besides that, the measurement of environmental factors that affect the vegetation is less supported by corresponding tools. This problem is a consequence of the incompatibility of research design that was made in the early stages. Consequently, the results obtained were less in accordance with the planned. Students' ability to make results interpretation relatively better, but less able to offer a solution as a form of problem-solving as planned in the proposal. 
Papers and posters as research products (artifacts) are averages well prepared by each group. The aspect that still needs to be improved was the writing skills. Students are still having trouble writing like geologists (Leydens \& Santi, 2006). To overcome this problem, need to be given assistance for physics students in preparing research products in written form. There were six of research products, but only two research products are considered worthy of publication, i.e. the paper on recognizing the nature of Tangkuban Parahu eruption based on the characteristics of rocks and a poster about the type and characteristics of the land on Tangkuban Parahu. They are relevant to all publication requirement aspect.

Students have time discipline in submitting the reports become a separate issue that should get more serious attention. Average the groups are not timely in collecting reports. The students should be trained to work in a predetermined time range (Becattini et al., 2015). Mogk \& Goodwin (2012) were identified, three important factors that must be understood in the practice of field activities, namely embodiment (total integration of body and mind to nature and the environment), creation and inscription (building a representation of natural phenomena), and initiation (related to norms and practices, selection and use of tools, and a general understanding of the assumptions, limitations and uncertainties). If these factors are well understood, it is certain that the student could succeed in carrying out the practice of field activities.

\section{CONCLUSION}

The opportunity to conduct VPD provides an opportunity to explore more details related to volcano problems. Various findings related to volcano-disaster zones, physiological changes in vegetation due to eruption effect, soil and rock characteristics around the volcano and community behavior in response to volcanic activity become new information for the volcanoes community. The finding related to the use of powdered sulfur rock as a means of skin beauty treatments open new research opportunities that are very potential to be developed. These results strongly support the lives of better communities around volcanoes. Based on the research result can be concluded that the volcano project as an important part of geoscience learning. They should improve physics student research skills about volcano. Through VPD, students were gaining the real experience to volcanic problem-solving systematically. The environment and social issues in the volcanic surrounding became interesting topics in geoscience learning and should stimulate students to think critically and work to resolve it through research. The research results from VPD also serve as a bridge to link the learning outcomes of geoscience in universities to the needs of the community and gives answer all issues about geoscience teaching is less considered. Through the VPD, students capable to uncover volcanic phenomena through research that can be utilized by the community, especially in adapting to life in the volcanoes surrounding.

\section{RECOMMENDATION}

This research is still in small sample. The next research is to facilitate in large sample and need to implementation in other level.

\section{ACKNOWLEDGEMENT}

This research received no specific grant from any funding agency in the public, commercial, or not-for-profit sectors.

\section{REFERENCES}

Adetunji, O.O., Ba, J.C.M., Ghebreab, W., Joseph, J.F., Mayer, L.P., \& Levine, R. (2012). Geoscience awareness program: A program for broadening participation of students in geoscience. Journal of Geoscience Education, 60, 234-240. 
Baber, L.D., Pifer, M.J., Colbeck, C., \& Furman, T. (2010). Increasing diversity in the geoscience: recruitment programs and student self-efficacy. Journal of Geoscience Education, 58 (1), 32-42.

Becattini, N., Cascini, G., \& Rotini, F. (2015). OTSM-TRIZ Network of Problems for evaluating the design skills of engineering students. World Conference: TRIZ FUTURE, TF 2011-2014. Procedia Engineering, 131, 689 - 700.

Buddington, A.M. (2006). A field-based, writing intensive undergraduate course on Pacific Northwest Geology. Journal of Geoscience Education, 54 (5), 584-587.

Çalişkan, O. (2011). Virtual field trips in education of earth and environmental science. Procedia Social and Behavioral Sciences, 15, 3239-3243.

Church, M. (2013). Refocusing geomorphology: field work in four acts. Geomorphology, 200 (15), 184-192.

Dominick, J., Buffington, L., Rowland, L., \& Warren, R. (2000). Undergraduate research: A review of the research literature, retrieved from https://view.officeapps.live.com.www.adelaide.edu.

Efstratia, D. (2014). Experiential education through project based learning. Procedia - Social and Behavioral Sciences, 152, 1256-1260.

Esteves, H., Ferreira, P., Vasconcelos, C., \& Fernandes I. (2013). Geological fieldwork: a study carried out with Portuguese secondary school students. Journal of Geoscience Education, 61, 318-325.

Fermeli, G., Steininger, F., Dermitzakis, M., Melendez, G., \& Page, K. (2014). Literacy and students' interest on geosciences-findings and result of GEOschols project. Geophysical Research Abstracts, 16 (EGU2014), 8678.

Fillipe de Baros, J., Almeida, P.A., \& Cruz, N. (2012). Fieldwork in geology: teachers' conception and practices. Procedia-Social and Behavioral Sciences, 47, 829-834. doi:10.1016/j.sbspro.2012.06.743.

Goldsmith, S.T., Trierweiler, A., Welch, S.A., Bancroft, A.M., Von Bargen, J.M., \& Carey, A. (2013). Transforming a university tradition into geoscience teaching and learning opportunity for the university community. Journal of Geoscience Education, 61, 280290.

Hope, M. (2009). The importance of direct experience: a philosophical defense of field work in human geography. Journal of Geography in Higher Education, Vol. 33, No. 2, 169182.

Ishiyama, J. (2002). Does early participation in undergraduate research benefit social science and humanities students? College Student Journal, 36 (3), 380-386.

Koretsky, C.M., Petcovic, H.L., \& Rowbotham, K.L. (2012). Teaching environmental geochemistry: An authentic inquiry approach. Journal of Geoscience Education, 60, 311-324.

Kortz, K.M., \& Kraft, K.J. (2016). Geoscience education research project: Student benefits and effective design of a course-based undergraduate research experience. Journal of Geoscience Education, 64 (1), 24-36.

LaDue, N.D., \& Manning, C.B. (2015). Next Generations Science Standard: a call to action for the geoscience community. GSA Today, 25 (2). doi:10.1130/GSATG233GW.1.

Lee, J.S., Blackwell, S., Drake, J., \& Moran, K.A. (2014). Taking a leap of faith: Redefining teaching and learning in higher education through project-based learning. Interdisciplinary Journal of Problem-based Learning, 8 (2).

Leydens, J.A., \& Santi, P. (2006). Optimizing faculty use of writing as a learning tool in geoscience education. Journal of Geoscience Education, 54 (4), 491-502.

Locke, S., Libarkin J., \& Chang, C.Y. (2012). Geoscience education and global development. Journal of Geoscience Education 60, 199-200.

Mccaffrey, K.J.W., Jones, R.R., Holdsworth, R.E., Wilson, R.W., Clegg, P., Imber, J., Holliman, N., \& Trinks, I. (2005). Unlocking the spatial dimension: digital technologies 
and the future of geoscience fieldwork. Journal of the Geological Society, 162, 927938.

Mogk, D.W., \& Goodwin, C. (2012). Learning in the field: Synthesis of research on thinking and learning in the geosciences. Geological Society of America Special Papers, 486, 131-163. doi: 10.1130/2012.2486(24).

Naikar, N. (2017). Cognitive work analysis: an influential legacy extending beyond human factors and engineering. Applied Ergonomics, 59, 528-540.

Nelson, K.G., Huysken, K., \& Kilibarda, Z. (2010). Assessing the impact of geoscience laboratories on student learning: Who benefits from introductory labs? Journal of Geoscience Education, 58, 43-50.

Petcovic, H.L., \& Stokes, A. (2014). Geoscientists' perceptions of the value of undergraduate field education. GSA Today, 24 (7). doi: 10.1130/GSATG196A.1.

Piburn, M.D., Kraft, K.H., \& Pacheco, H. (2011). A New Century for Geoscience Education Research. Committee on the Status, Contributions, and Future Directions of Discipline-Based Education Research. Retrieved from https://sites.nationalacademies.org/cs/groups/dbassesite/documents/webpage/dbasse_07 2590.pdf.

Reisberg, L. (1998). Research by undergraduate proliferates, but is some of it just glorified homework? Chronicle of Higher Education, 44 (37), A45-A46.

Roberts, D., Bradley, E., Roth, K., Eckmann, T., \& Still, C. (2010). Linking physical geography education and research through the development on an environmental sensing network and project based learning. Journal of Geoscience Education, 58 (5), 262-274.

Scott, K.S. (2014). A multilevel analysis of problem-based learning design characteristics. The Interdisciplinary Journal of Problem-Based Learning, 8 (2).

Seymour, E., Hunter, A., Laursen, S., \& Deantoni, T. (2004). Establishing the benefits of research experiences for undergraduates in the sciences: First findings from a three-year study. Science Education, 88 (4), 493-534.

Stokes, A., Magnier, K., \& Weaver, R. (2011). What is use field work? Conceptions of students and staff in geography and geology. Journal of Geography in Higher Education, 35 (1), 121-141.

Stumpf, A.J. (2012). Development of a database for geological field observations, westcentral British Columbia (part of NTS 093L); in Geoscience BC Summary of Activities 2011, Geoscience BC, Report 2012-1, p. 53-58.

Tongsakul, A., \& Jitgarun K. (2006). Empowering student's learning achievement through project based learning as perceived by electrical instructions and students. Proceeding of the edu.com 2006 International Conference Engagement and Empowerment: New Opportunities for Growth in Higher Education, Edith Cowan University, Perth Western Australia. 22-24 November 2006. Retrieved from http://ecueduan/ceducom/110.

Verschuren, P., \& Doorewaard, H. (2010). Designing a Research Project. The Hague: Eleven International Publishing. Retrieved from https://www.boomhogeronderwijs.nl/documenten/9789059315723_inkijkexemplaar.pdf

Waldron, J.W.F., Locock, A.J., and Pujadas-Botey, A. (2016). Building an Outdoor Classroom for Field Geology: The Geoscience Garden. Journal of Geoscience Education. Vol. 64, No. 3, pp. 215-230.

Willison, J. (2012). When academics integrate research skill development in the curriculum. Higher Education Research and Development, 31(6), 905-919. doi: $10.1080 / 07294360.2012 .658760$.

Wulf, A.H. (2013). Portals for undergraduate research in geology curricula. EOS, 94 (6), 6168. 
Wysession, M.E. (2013). The next generation science standard and the earth and space sciences. Published in the April/May issues of NSTA's K-12 journals. Retrieved from http://nstahosted.org/pdfs/ngss/resources/201304 NGSS-Wysession.pdf.

Young, D., Trimboli, S.R., Toomey, R.S., \& Byl, T. (2016). Undergraduate Research Projects Help Promote Diversity in the Geosciences. Mammoth Cave Research Symposia. Paper 12. Retrieved from http://digitalcommons.wku.edu/mc reserch_symp/11th_Research_Symposium_2016.

Zoldosova, K., \& Prokop, P. (2006). Education in the field influences children's ideas and interest toward science. Journal of Science Education and Technology, 15(3), 304-313. doi: 10.1007/s10956-006-9017-3. 